Original Research Paper

\title{
Sunfish's (Mola spp.) Habitat Characteristics on their Appearance at Dive Tourism Depths in Nusa Penida Waters, Bali
}

\author{
Dewi SLKT', MM Kamal ${ }^{1 *}$, T Tarsidin², G Yulianto' \\ ${ }^{1}$ Department of Aquatic Resources Management, Faculty of Fisheries and Marine Science, IPB University, Bogor, \\ Indonesia \\ ${ }^{2}$ Lembong Discovery Dive Center, Nusa Lembongan Island, Bali, Indonesia
}

\author{
Article History \\ Received : January $08^{\text {th }}, 2021$ \\ Revised : January $15^{\text {th }}, 2021$ \\ Accepted : January $20^{\text {th }}, 2021$ \\ Published : January $27^{\text {th }}, 2021$ \\ *Corresponding Author: \\ Mohammad Mukhlis Kamal, \\ Department of Aquatic Resource \\ Management, Faculty of Fisheries and \\ Marine Science, IPB University, Bogor, \\ Indonesia; \\ Email: \\ mohammadmukhliskamal@gmail.com
}

\begin{abstract}
The sunfish or mola fish (Mola spp.) is one of marine tourism' icon in Nusa Penida waters where they appear seasonally. This study was aimed to observe the habitat characteristics of mola fish at the depths of diving tourism where they are visible. The research was conducted from July to December 2019 using survey and descriptive methods to obtain information of mola fish animal linked to habitat conditions. On its appearance data on depths, temperatures, currents, and the presence of symbiotic fishes were observed directly assisted by dive center operators. By comparing the morphological characteristics shown photographically, it is assumed that mola fish in study area is composed by two species, $M$. alexandrini and M. mola. The highest individual record was in September and decreasing along the incoming months. Mola fish prefers calm deeper water with lower temperatures coincides with the presence of cleaning reef fishes.
\end{abstract}

Keywords: Mola fish; Nusa Penida; Appearance; Habitat

\section{Pendahuluan}

Ikan mola dengan nama umum sunfish merupakan anggota famili Molidae mendiami perairan beriklim tropis dan sedang. Hewan ini termasuk ikan bertulang sejati (osteichthyes) terbesar dan terberat di dunia (Pope et al. 2010), serta tergolong ikan purba yang masih eksis hingga kini. Hal ini dicirikan dengan tubuh yang tidak memiliki ekor melainkan termodifikasi menjadi clavus. Ikan mola muncul ke permukaan untuk berjemur dan membiarkan burung laut membersihkan serta menghilangkan parasit di tubuhnya (Dewar et al. 2010). Tingkah laku yang unik tersebut sehingga ikan ini dinamakan sunfish (ikan matahari).

Ikan mola dapat ditemui pada beberapa daerah di Indonesia, salah satunya perairan Nusa Penida. Jenis ikan mola yang telah ditemui di perairan Nusa Penida adalah jenis Mola ramsayi (Thys et al. 2016), yang menurut IUCN status konservasinya masih unrecorded atau tidak ada rekam jejak mengenai spesies ini. Ikan ini merupakan ikan musiman yang muncul di perairan Nusa Penida dan juga merupakan salah satu maskot wisata bahari di perairan tersebut. Ikan ini dapat ditemui pada bulan juli hingga september di perairan Nusa Penida (Welly et al. 2011).

Perairan Nusa Penida merupakan bagian dari segitiga terumbu karang dunia (Coral triangle) yang memiliki keanekaragaman hayati tinggi. beberapa marine mega fauna selain ikan mola, yaitu lumba-lumba, pari manta, penyu, hiu paus, dan sempat ditemukan kemunculan hiu putih (white shark) di perairan ini. Kemunculan ikan mola di perairan Nusa Penida memiliki nilai penting baik dari segi ekonomi maupun ekologi, namun masih sedikit kajian terkait kemunculan biota ini. Beberapa parameter oseanografi fisika (kedalaman, suhu, arus), makanan, keberadaan biota yang bersimbiosis, serta kondisi iklim adalah beragam faktor yang mempengaruhi 
kemunculan ikan mola (Dewar et al. 2010; Putra et al. 2015; Thys et al. 2015; Salim et al. 2017). Penelitian ini merupakan kajian terhadap kemunculan ikan mola yang dikaitkan dengan kondisi habitat perairan pada kedalaman wisata selam.

\section{Bahan dan Metode}

\section{Waktu dan Lokasi Penelitian}

Penelitian dilakukan pada bulan Agustus 2019 hingga Januari 2020. Penelitian terbagi atas tahapan pra-survei dan survei lapang untuk memeroleh parameter lingkungan yang memengaruhi kemunculan ikan mola. Pengamatan dilakukan pada beberapa titik penyelaman (dive site) yang menjadi spot kemunculan, yaitu Crystal Bay, Toya Pakeh, Blue Corner, Sental Point, Ped, SD Point, PMG, dan Manta Point (Gambar 1).

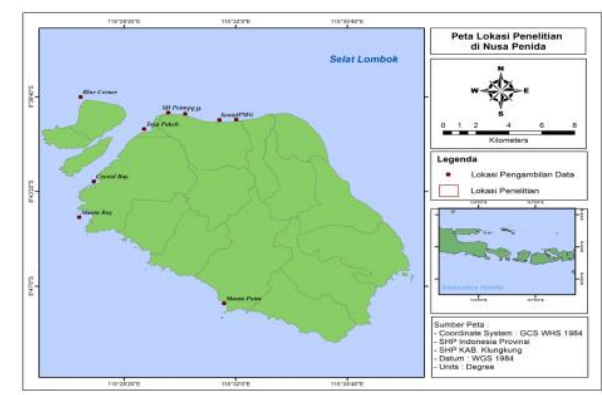

Gambar 1. Lokasi penyelaman (dive sites) di Perairan Nusa Penida tempat dimana ditemukan kemunculan ikan mola

\section{Metode Pengumpulan Data}

Data penelitian terdiri atas data primer dan data sekunder. Pengambilan data primer dilakukan dengan metode wawancara dan observasi langsung. Responden dipilih secara sengaja dari masyarkat yang ditemui sekitar pesisir Nusa Penida (purposive sampling). Observasi dilakukan untuk mendapatkan data jumlah, lokasi, waktu, kedalaman, suhu perairan, tingkah laku, arus, cuaca, dan biota bersimbiosis pada saat kemunculan ikan mola. Peneliti dibantu oleh penyelam dari beberapa dive center (Nomads, Manta Dive, Blue Corner, Octopus dan Water Sport) dalam pengambilan data kemunculan ikan mola pada bulan Agustus sampai Desember 2019. Pengamatan tingkah laku ikan mola dilakukan dengan penyelaman, dimana pengukuran suhu dan kedalaman dilakukan menggunakan dive computer. Data sekunder meliputi data kemunculan dan dokumentasi ikan mola selama bulan JuliDesember 2019. Dokumentasi tersebut diperoleh melalui komunikasi pribadi dengan salah satu dive guide Tatang Tarsidin (2019).

\section{Analisis Data}

Data yang diperoleh dianalisis secara deskriptif. Deskripsi morfologi ikan mola berdasarkan hasil pengamatan dari dokumentasi ikan tersebut. Data-data tersebut kemudian merujuk kepada kepustakaan yang tersedia (Fruser-Bruner 1951; Sawai et al. 2017; Riawan et al. 2019). Regresi linier berganda digunakan untuk mencari korelasi antara kedalaman dan suhu perairan dengan kemunculan ikan mola. Asumsinya adalah adanya hubungan linier antara variabel independen dengan masingmasing prediktornya. Persamaan model tersebut adalah (Janie 2012):

$$
\mathrm{Y}=\alpha+\beta_{1} \mathrm{X}_{1}+\beta_{2} \mathrm{X}_{2}+\varepsilon_{\mathrm{i}}
$$

Keterangan :

$\mathrm{Y} \quad=$ Nilai peubah yang dipengaruhi

(Jumlah kemunculan ikan mola)

$\alpha \quad=$ Konstanta

$\beta_{1}-\beta_{2}=$ Koefisien regresi variabel independen

$\mathrm{X}_{1} \mathrm{X}_{2}=$ Nilai Peubah yang memengaruhi (kedalaman $(\mathrm{m})$ dan suhu $\left({ }^{\circ} \mathrm{C}\right)$ )

$\varepsilon_{\mathrm{i}} \quad=$ Galat percobaan ke-i

Data biologi dan fisika perairan meliputi kejadian kemunculan, suhu, kondisi arus, keberadaan biota yang bersimbiosis dengan ikan mola dan kedalaman perairan. Data tersebut dicatat dan dideskripsikan dengan bantuan Microsoft Excel dan SPSS. Data hasil perhitungan disajikan dalam tabel dan diagram, kemudian dibandingkan antara teori dengan referensi yang ada. Distribusi jumlah individu dan lokasi kemunculan ikan mola pada setiap koordinat dive site dianalisis dengan aplikasi QGIS, sehingga dapat disajikan dalam peta.

\section{Hasil dan Pembahasan}


Dewi et al. (2021). Jurnal Biologi Tropis, 21 (1): 149 - 156

DOI: http://dx.doi.org/10.29303/jbt.v21i1.2442

Dugaan Spesies Ikan Mola di Perairan Nusa Penida

Hasil dokumentasi ikan mola di lokasi studi memperlihatkan ciri-ciri morfologi clavus yang berbeda satu dengan yang lainnya (Gambar 2). Pada Gambar 2A terlihat memiliki jarak ossicle (tulang-tulang kecil antara lekukan pada ujung clavus) yang lebih sempit dibandingkan dengan Gambar 2B. Ikan mola pada 2A tidak memiliki smooth band sebagaimana diperlihatkan 2B. Berdasarkan deskripsi pertelaan spesies dari Fraser-Bruner (1951), diduga secara berurutan spesies ikan mola di Perairan Nusa Penida merujuk kepada jenis M. alexandrini dan M. mola.

\section{Kemunculan Ikan Mola}

Lokasi kemunculan ikan mola yang diamati berada di dalam zona pariwisata KKP Nusa Penida (DKP 2016) Kemunculan tertinggi terjadi bulan September 2019, yaitu sebanyak 38 individu dalam 22 kali kemunculan. Kemunculan tertinggi kedua adalah bulan November yaitu sebanyak 22 ekor dari 15 kemunculan (Gambar 3). Ikan mola masih ditemukan hingga bulan Desember namun jumlahnya sudah menurun. Berdasarkan hal tersebut diduga bahwa kemunculan ikan mola dapat berada pada rentang waktu yang lebih lama dibandingkan informasi masyarakat yang mengatakan antara Juli - Oktober.

Frekuensi kemunculan tertinggi sekaligus jumlah individu terbanyak (19 kali dan 27 ekor) ditemukan di Crystal Bay. Untuk frekuensi kemunculan tertinggi berikutnya Sental (15 kali, 18 individu), namun menurut jumlah individu tertinggi diperoleh di Blue Corner (7 kali, 23 individu) (Gambar 4).

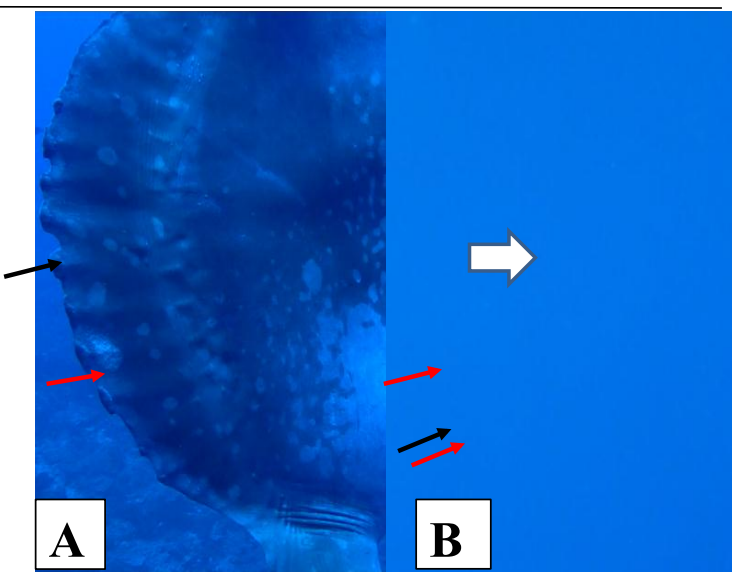

Gambar 2. Perbedaan ciri-ciri clavus yang ditemukan saat pengamatan, panah putih menunjukan smooth band (Sumber: Tatang Tarsidin (Dokumentasi pribadi, Desember 2019))

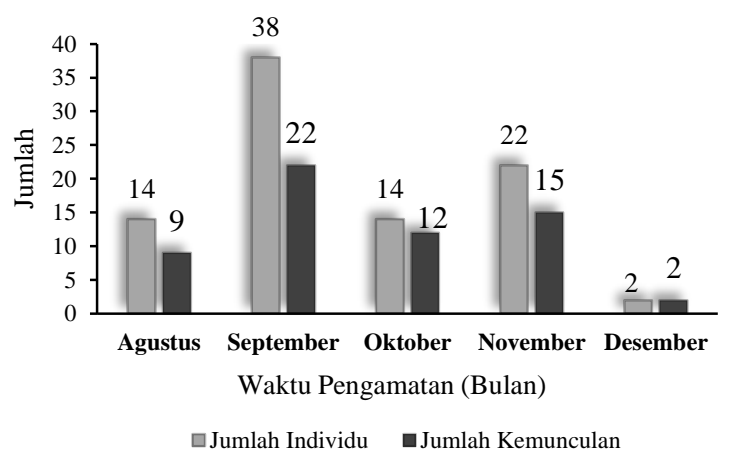

Gambar 3. Frekuensi kemunculan dan jumlah individu ikan mola selama penelitian

Kemunculan ikan mola di perairan Nusa Penida dapat dibagi atas kemunculan berkelompok (2-14 individu) dan tidak berkelompok (1 individu). Berdasarkan informasi diveguide, untuk pertama kali ditemukannya ikan mola berjumlah 14 ekor dalam satu kemunculan. Fenomena kemunculan secara menyendiri (soliter) maupun berkelompok (schooling) merupakan fenomena biasa, namun untuk yang kategori kedua maksimal jumlahnya antara 4 - 6 individu.

Terdapat tiga aktivitas utama yang teramati saat kemunculan ikan mola, yaitu cleaning (66\%), swimming (31\%) dan jumping (3\%). Aktivitas jumping dilakukan ikan setelah aktivitas cleaning selesai. Hal ini diduga bahwa jumping dilakukan untuk membersihkan sisasisa parasit yang menempel pada tubuhnya. Saat cleaning ikan mola seperti melayang-layang tanpa pergerakan di kolom perairan sehingga 
memudahkan ikan kepe-kepe dari jenis bannerfish (Gambar 5) untuk membersihkan tubuh ikan mola. Aktivitas tersebut menguntungkan bagi ikan mola untuk membersihkan tubuh dari parasit dan bannerfish yang menjadikan parasit sebagai sumber makanan (simbiosis mutualisme). Jenis ikan karang ini diduga spesiesnya adalah Heniochus diphreutes.

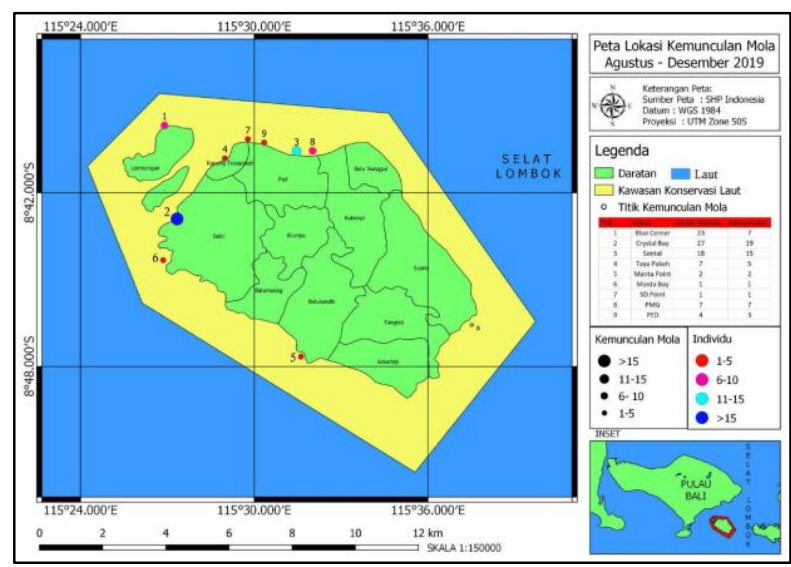

Gambar 4. Peta frekuensi kemunculan dan jumlah individu ikan mola pada lokasi pengamatan di perairan Nusa Penida

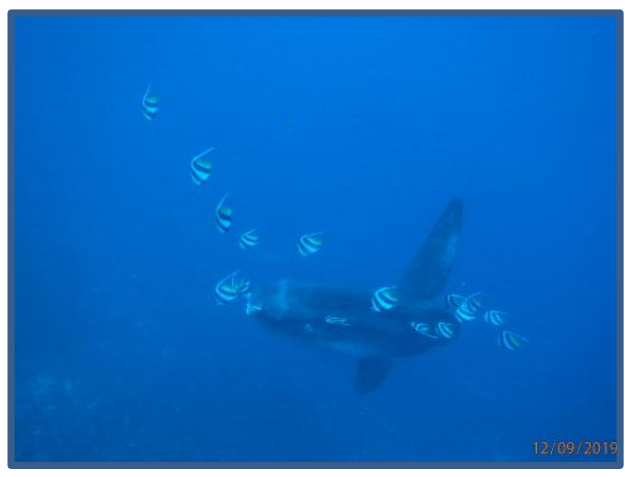

Gambar 5. Aktivitas cleaning yang dilakukan ikan mola dengan bantuan ikan karang pembersih (Sumber: Tatang Tarsidin (Dokumentasi pribadi, Desmber 2019))

\section{Keterkaitan Kondisi Habitat dengan Kemunculan Ikan Mola}

Selama pengamatan, frekuensi kemunculan mola yang teramati dibagi dalam 3 zona waktu, yaitu ZW I (07:00-09:00), ZW II (09:01-11:00), dan ZW III. (11:01-14:00). Frekuensi kemunculan ikan mola tertinggi terjadi pada ZW I (Gambar 6) pada kedalaman rata-rata 26,8 $\mathrm{m}$ (Gambar 7) dan suhu rata-rata sebesar $21,4^{\circ} \mathrm{C}$ (Gambar 8). Berdasakan hal tersebut, diduga perairan yang dalam dengan suhu yang rendah lebih disukai oleh ikan mola.

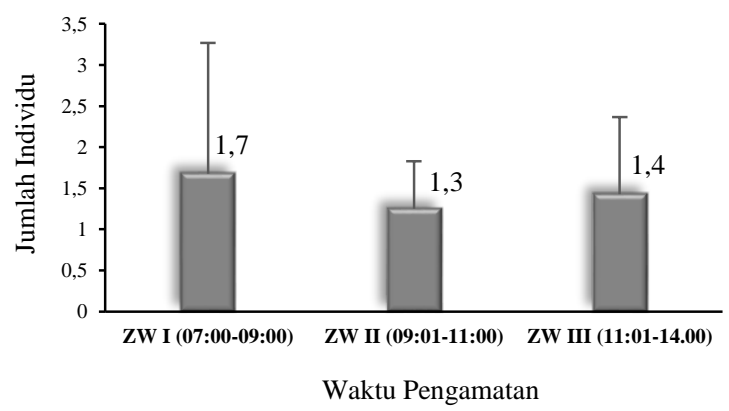

Gambar 6. Rata-rata kemunculan ikan mola di perairan Nusa Penida dibagi menjadi tiga zona waktu pengamatan.

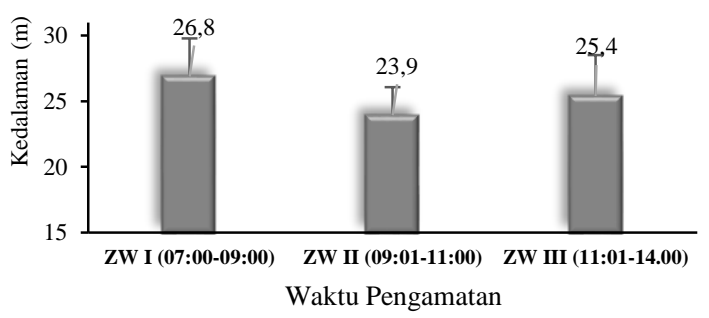

Gambar 7. Rata- rata kedalaman ketika kemunculan ikan mola di perairan Nusa Penida pada tiga zona waktu pengamatan.

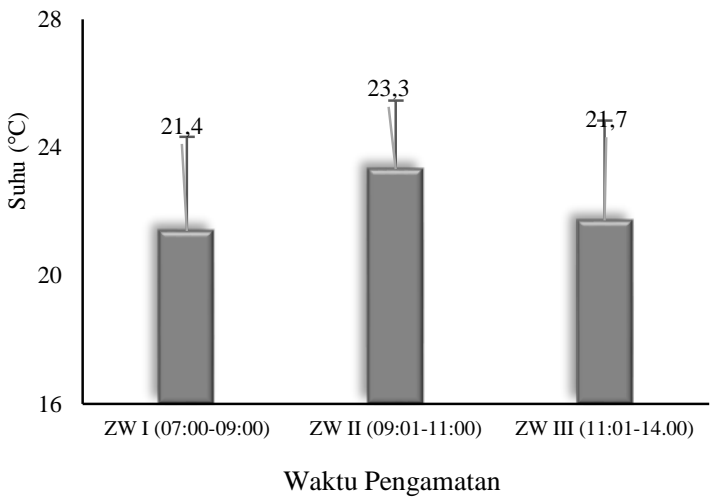

Gambar 8. Rata- rata suhu ketika kemunculan ikan mola di perairan Nusa Penida pada tiga zona waktu pengamatan

Kondisi arus pada saat kemunculan ikan mola bervariasi, dimulai dari tidak ada arus (none) hingga arus yang kuat (strong). Sebesar $48 \%$ kondisi arus saat pengamatan merupakan 
arus tenang (calm) (Gambar 9). Pada kondisi arus kuat, jumlah individu ikan mola yang ditemukan 3\% dari total yang teramati. Saat arus kuat tersebut sebanyak dua kali ditemukan ikan sedang melakukan cleaning, meskipun salah satunya terjadi ketika arus berganti dari kuat menjadi tenang. Hal ini merupakan suatu hal tidak biasa karena umumnya aktivitas cleaning (membersihkan diri) tidak terjadi pada kondisi arus bergejolak.

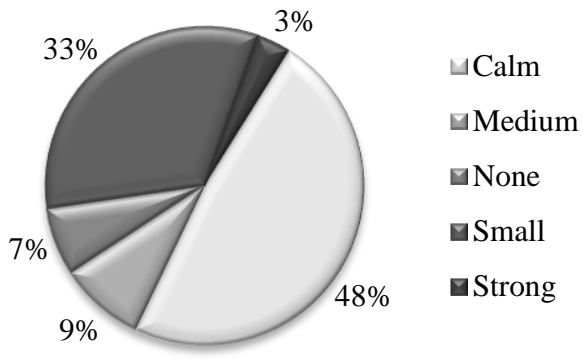

Gambar 9. Kondisi aeus yang teramati selama kemunculan ikan mola.

Selama proses cleaning ikan mola sering ditemukan berasosiasi dengan ikan karang pembersih, yaitu bannerfish (Heniochus diphreutes), emperor angelfish (Pomacanthus imperator), dan moorish idol (Zanclus cornutus). Bannerfish merupakan ikan karang pembersih tertinggi teramati yaitu sebesar $65 \%$, diikuti emperor sebanyak $18 \%$ dan moorish idol 17\% (Gambar 10). Berdasarkan informasi yang di dapat dari dive guide, kemunculan bannerfish dalam jumlah banyak di kolom perairan dapat menjadi pertanda akan hadirnya ikan mola di lokasi tersebut.

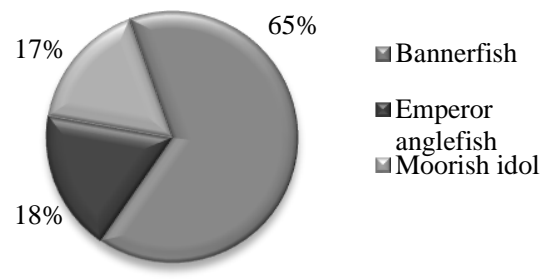

Gambar 10. Jenis ikan karang pembersih parasit pada ikan mola di perairan Nusa Penida.

Hasil analisis regresi hubungan antara suhu dan kedalaman (variabel independen) dengan kemunculan ikan mola (variabel dependen) mendapatkan persamaan sebagai berikut $(n=58)$.
$\mathrm{Y}=1,914+0,07$ (Kedalaman) -0.1

(Suhu)

$\mathrm{t}_{\text {hitung }} \quad(2,993)^{*} \quad(-1,91)^{* *}$
$n=58 ; \quad R^{2}=0,227 ; \quad F_{\text {hitung }}=8,077$
$t_{-}$test $: *$ signifikan at level $\alpha=0,05$
$t_{\text {test }}: * *$ signifikan at level $\alpha=0,1$
$\bar{F}_{\text {_test }}: *$ signifikan at level $\alpha=0,01$

Berdasarkan persamaan tersebut menunjukan bahwa setiap bertambahnya kedalaman maka akan bertambah jumlah kemunculan ikan mola sebesar 0,07. Berbeda dengan suhu, seiring bertambahnya suhu, maka jumlah kemunculan ikan mola akan menurun sebesar 0,1. Berdasarkan uji t, pada selang kepercayaan $95 \%$ diduga kedalaman berpengaruh terhadap kemunculan ikan mola. Berbeda halnya dengan suhu yang dapat memengaruhi kemunculan ikan mola pada selang kepercayaan 90\%. Berdasarkan hal tersebut diduga kedalamaan memiliki pengaruh terhadap kemunculan ikan mola yang lebih besar dibandingkan suhu. Hasil koefisien determinasi $\left(\mathrm{R}^{2}\right)$ diperoleh sebesar $22,7 \%$. Hal ini menunjukan kemunculan ikan mola secara bersama-sama dipengaruhi oleh suhu dan kedalaman sebesar $22,7 \%$, sedangkan sisanya dipengaruhi faktor lain. Faktor tersebut, diduga di antaranya adalah keberadaan ikan karang pembersih, kedalaman perairan, ketersediaan makanan, kondisi iklim, dan lainnya.

\section{Pembahasan}

Ikan mola yang telah teridentifikasi berdasarkan pengamatan sebelumnya oleh Thys et al. (2016) di perairan Nusa Penida adalah Mola ramsayi. M. ramsayi merupakan sinonim dari M. alexandrini (Nyegaard dan Sawai 2018). Berdasarkan hasil pengamatan melalui dokumentasi dari Bapak Tatang Tarsidin terdapat ciri morfologi yang berbeda. Kecurigaan terhadap perbedaan ciri morfologi terlihat jelas pada bagian clavus ikan tersebut (Gambar 2). Ikan mola pada gambar 2B memiliki smooth band dan lebar ossicle yang lebih sempit dibandingkan dengan jarak diantaranya. Menurut Fraser-Burnner (1951) ciri tersebut tidak dimiliki oleh $M$. ramsayi. Berdasarkan uraian di atas dapat diduga bahwa ada dua spesies, yaitu M. ramsayi dan M. mola. Namun hal ini perlu dikaji lebih lanjut, 
dikarenakan masih terdapat ciri-ciri lainnya yang tidak dapat teramati dengan jelas dari gambar, seperti jumlah ossicle, jumlah fin rays dan lainnya.

Penelitian ini mengkonfirmasi bahwa kemunculan ikan mola dipengaruhi oleh suhu, kedalaman, arus, dan biota yang berasosiasi dengannya (Dewar et al. 2010; Putra et al. 2015; Thys et al. 2015). Jumlah kemunculan tertinggi ikan mola di perairan Nusa Penida ditemui pada rata-rata suhu yang lebih rendah $\left(21,4^{\circ} \mathrm{C}\right)$ pada rata rata kedalaman tertinggi $(26,8 \mathrm{~m})$. Pengamatan sebelumnya mencatat ikan mola beraktivitas pada rentang suhu $10^{\circ} \mathrm{C}$ hingga $27,5^{\circ} \mathrm{C}$, dan kemunculan tertinggi berada pada suhu perairan yang lebih rendah (Thys et al. 2016; Tito dan Susilo 2017). Penelitian sebelumnya yang dilakukan oleh Putra et al. 2015, yaitu suhu permukaan laut (SPL) berpengaruh sebesar 20\% terhadap kemunculan ikan. Penelitiaan saat ini menemukan bahwa kedalaman dan suhu berpengaruh secara bersama-sama sebesar $22,7 \%$ terhadap kemunculan ikan mola, sedangkan sisanya dipengaruhi oleh faktor lain, yaitu sebesar $77,3 \%$ yang mempengaruhi kemunculan ikan mola. Faktor lain tersebut diduga adalah kehadiran ikan karang pembersih, arus, kegiatan wisata, perikanan tangkap dan faktor lainnya.

Perairan Nusa Penida dikenal dengan pulau yang memiliki arus yang kuat dan memiliki tebing-tebing di dasar laut yang dapat berdampak pada jumlah terjadinya upwelling (DKP 2016). Hal ini menyebabkan suhu perairan pulau ini cenderung lebih dingin. Hasil dari wawancara yang dilakukan pada beberapa dive guide, bahwa ikan mola muncul ke permukaan diikuti dengan perubahan suhu perairan lebih dingin, yang diduga erat kaitannya dengan fenomena upwelling di perairan tersebut. Menurut Thys et al. (2015) terjadinya upwelling di suatu perairan dapat menciptakan habitat untuk mencari makanan $M$. mola.

Ikan mola selain pada lokasi wisata selam, juga sering ditemukan oleh para nelayan ketika beraktivitas di sekitar Selat Lombok. Selat Lombok merupakan salah satu perairan yang dilintasi oleh Arlindo, yaitu arus dari Samudera Pasifik menuju Samudera Hindia. Arlindo melintasi Selat Makasar menuju ke Selatan melewati pulau Bali hingga Nusa
Tenggara Timur (Abida et al. 2015). Hasil tracking ikan mola yang dilakukan Thys et al. (2016), menunjukan pergerakan horizontal ikan tersebut hingga laut Sawu dan perairan pulau Alor. Selain itu, ikan mola setelah melakukan cleaning akan berenang ke selatan (Samudera Hindia) perairan yang lebih dalam. Berdasarkan hal tersebut diduga ikan mola melakukan migrasi dengan bantuan dari Arlindo. Namun masih diperlukan kajian lebih lanjut terkait hal ini.

Ikan mola pada penelitian ini sempat ditemukan dalam kondisi arus yang kuat serta ada pula berenang dengan cepat ketika hendak jumping dan terancam. Berdasarkan informasi dari nelayan dan masyarakat sekitar, ikan mola dapat jumping dengan ketinggian 0,5-1 m menembus permukaan air. Menurut Watanabe dan Sato (2008), sirip dorsal dan ventral mola memiliki bentuk identik dan masa otot sama meskipun bentuk otot lebih besar pada bagian dorsal. Selanjutnya, Yasemi dan Bejgan (2014) mengatakan bahwa ikan mola memiliki daya dorong lokomotif utama yang kuat terdapat di sirip anal dan sirip dorsal ikan tersebut. Ikan mola tidak memiliki gelembung renang, sehingga untuk mempertahankan tubuhnya pada kolom air dikompensasi dengan kemampuan daya apung netral terhadap kedalaman. Hal tersebut membantu ikan mola untuk mampu melayang di kolom perairan ketika cleaning. Hal ini dikarenakan ikan mola memiliki jaringan gelatin subkutan hampir di seluruh bagian tubuhnya (Watanabe dan Sato 2008).

Ikan mola memiliki kemampuan berenang yang cukup baik, sehingga dapat mempertahankan diri pada kondisi arus yang kuat. Ikan karang pembersih memiliki keterbatasan ruang gerak untuk melakukan aktivitas cleaning terhadap ikan mola pada kondisi arus yang kuat (Putra et al. 2015). Saat kondisi arus kuat ikan karang pembersih akan berlindung di balik karang untuk mempertahankan diri. Hal ini yang menyebabkan ikan mola cenderung ditemukan pada arus yang lebih tenang. Melihat sebagian besar aktivitas ikan mola yang teramati adalah cleaning, hal ini menunjukan bahwa keberadaan ikan karang pembersih di Perairan Nusa Penida memiliki peranan penting terhadap kemunculan ikan mola. Ikan karang pembersih seperti bannerfish merupaka indikator alami suatu 
periaran. Hal ini juga menunjukan bahwa kondisi perairan yang baik dapat berdampak pada kemunculan ikan mola di periaran Nusa Penida.

\section{Kesimpulan}

Karakteristik habitat yang memengaruhi kemunculan ikan mola di perairan Nusa Penida, yaitu perairan lebih dalam dimana terdapat kelimpah ikan karang pembersih disertai suhu perairan yang dingin dan kondisi arus tenang. Suhu dan Kedalaman perairan memengaruhi kemunculan ikan mola sebesar 22,7 \%, sebanyak 77,3\% diduga dipengaruhi oleh faktor lainnya seperti, kehadiran ikan karang pembersih, arus, dan faktor lingkungan lainnya. Kemunculan ikan mola di perairan Nusa Penida terjadi antara Juli hingga Desember, jumlah kemunculan ikan mola tertinggi berada pada bulan September.

\section{Ucapan Terima Kasih}

Terimakasih kami sampaikan kepada para pemandu selam khususnya dari Cristal Bay dan Blue Corner. Apresiasi dan terimakasih khusus kepada Bapak Tatang Tarsidin yang sangat membantu dalam mencari dan memberikan informasi terkait kegiatan wisata selam.

\section{Referensi}

Abida RF, Pranowo WS, Pratomo Y, \& Kisnarti EA. (2015). Identifikasi komponen harmonik di Selat Lombok berdasarkan data arus time series. Depik. 4(1): 24-32. DOI:

http://dx.doi.org/10.13170/depik.1.1.2361

Dewar H, Thys TM, Teo SLH, Farwell C, O'Sullivan J, Tobayama T, Soichi M, Nakatsubo T, Kondo Y, Okada Y, Lindsay DJ, Hays GC, Walli A, Weng K, Streelman JT, ... \& Karl SA. (2010). Satellite tracking the world's largest jelly predator, the ocean sunfish, Mola mola, in the Western Pacific. Journal of Experimental Marine Biology and Ecology. 393(1-2): 32-42. www. https://oceansunfish.org/DewarEtAlJEM $\underline{\text { BE.pdf }}$
[DKP] Dinas Kelautan dan Perikanan Denpasar (2016). Rencana Pengelolaan dan Zonasi Kawasan Konservasi Perairan (KKP) Nusa Penida Kabupaten Klungkung, Provinsi Bali. Denpasar (ID): DKP Bali. http://kkji.kp3k.kkp.go.id/index.php/doku men/publikasi/buku/finish/2-buku/814buku-1-rencana-pengelolaan-kkp-nusapenida-v2

Fraser-Brunner A. (1951). The ocean sunfishes (family Molidae). Bulletin of the British Museum (Natural History) Zoology. 1(6): 87-121.

https://www.scirp.org/(S(lz5mqp453edsn p55rrgjct55))/reference/ReferencesPapers .aspx?ReferenceID=2197874

Janie DNA. (2012). Statistik Deskriptif \& Regresi Linier Berganda dengan SPSS. Semarang (ID): Semarang University Press.

https://repository.usm.ac.id/files/bookusm /B208/20170519022209-StatistikDeskriptif-\&-Regresi-Linier-Bergandadengan-SPSS.pdf

Nyegaard M, \& Sawai E. (2018). Species identification of sunfish specimens (genera Mola and Masturus, family Molidae) from Australian and New Zealand natural history museum collections and other local source. Elsevier. $\quad 19$ : 2404-2415. DOI: $\underline{10.1016 / \text { j.dib.2018.07.015 }}$

Pope EC, Hays GC, Thys TM, Doyle TK, Sims DW, Queiroz N, Hobson VJ, Kubicek L, ... \& Houghton JDR. (2010). The biology and ecology of the ocean sunfish Mola mola : a review of current knowledge and future research perspective. Reviews in Fish Biology and Fisheries. 20(4):471487. DOI: $10.1007 / \mathrm{s} 11160-009-9155-9$

Putra MIH, Indrayanti E, \& Zainuri M. (2015). Variabilitas suhu dan kecepatan arus terhadap keberadaan ikan matahari (Mola ramsayi) di perairan kepulauan Nusa Penida. Journal Oseanografi. 4(3): 545555. 
https://ejournal3.undip.ac.id/index.php/jo ce/article/view/9048/8794

Riawan IMO, Setiabudi GI, Merdana M, \& Mariasa IPM. (2019). First molecular identification of sunfish in North Bali water. Journal of Advances in Tropical Biodiversity and Environmental Sciences. 3(1):

12-16.

DOI:

10.24843/atbes.v03.i01p04

Salim D, Yulianto, Baharuddin. Karakteristik parameter oseanografi fisika kimia perairan pulau Kerumputan Kabupaten Kotabaru Kalimantan Selatan. Jurnal Enggano. 2(2):218-228. https://ejournal.unib.ac.id/index.php/jurna lenggano/article/view/2820/1339

Thys TM, Ryan JP, Dewar H, Perle CR, Lyons K, O'Sullivan J, Farwell C, Howard MJ, Weng KC, Lavaniegos BE, Castro GG, Bojorquez LEM, Hazen EL, ... \& Bograd SJ. (2015). Ecology of the Ocean Sunfish, Mola mola, in the southern California Current System. Journal of Experimental Marine Biology and Ecology. 471: 64-76. https://core.ac.uk/download/pdf/2354118 47.pdf

Thys TM, Ryan JP, Weng KC, Erdmann M, \& Tresnati J. (2016). Tracking a marine ecotourism star: movements of the short ocean sunfish Mola ramsayi in Nusa Penida Bali, Indonesia. Journal of Marine Biology. 3(1): 1-6. https://doi.org/10.1155/2016/8750193

Tito CK, \& Susilo E. (2017). The correlation of upwelling phenomena and ocean sunfish occurrences in Nusa Penida, Bali. In 2nd International Conference on Tropical and Coastal Region Eco Development [Internet]. Bali (ID): IOP Conf. Ser.: Earth and Environ. Sci. 55: (1-9). doi:10.1088/1755-1315/55/1/012031

Watanabe Y, \& Sato K. (2008). Functional dorsoventral symmetry in relation to liftbased swimming in the ocean sunfish Mola mola. PloS One. 3(10). https://doi.org/10.1371/journal.pone.0003 $\underline{446}$

Welly MD, Primaoktasa IP, \& Tatas MJ. (2011). Profil wisata bahari Nusa Penida, Kabupaten Klungkung, Propinsi Bali. Coral Triangle Center (CTC). https://www.coraltrianglecenter.org/publi cations/

Yasemi M, \& Bejgan ARN. (2014). The first record of southern ocean sunfish, Mola ramsayi from Northern Oman Sea, Iran. Iranian Journal of Fisheries Sciences. 13(1): 242-246. http://jifro.ir/article-11442-en.pdf 